\title{
Effects of Supplementation of Ferulic Acid (FA) on Growth Performance, Activities of Digestive Enzymes, Antioxidant Capacity and Lipid Metabolism of Large Yellow Croaker (Larimichthys crocea) Larvae
}

\section{Wenxuan Xu}

Ocean University of China - Yushan Campus

Wenxing Huang

Ocean University of China - Yushan Campus

Chuanwei Yao

Ocean University of China - Yushan Campus

Yongtao Liu

Ocean University of China - Yushan Campus

Zhaoyang Yin

Ocean University of China - Yushan Campus

Kangsen Mai

Ocean University of China - Yushan Campus

Qinghui Ai ( $\nabla$ qhai@ouc.edu.cn )

Ocean University of China

\section{Research Article}

Keywords: Larimichthys crocea, Ferulic acid, Digestive enzymes, Antioxidant capacity, Lipid metabolism

Posted Date: February 2nd, 2022

DOl: https://doi.org/10.21203/rs.3.rs-1130999/v1

License: (c) (i) This work is licensed under a Creative Commons Attribution 4.0 International License. Read Full License 


\section{Abstract}

A 30-day feeding trial was conducted to investigate effects of supplementation of ferulic acid (FA) on growth performance, activities of digestive enzyme, antioxidant responses and lipid metabolism of the large yellow croaker (Larimichthys crocea) larvae. Four isonitrogenous and isolipidic micro-diets were formulated with graded levels of $F A(0,20,40$, and $80 \mathrm{mg} / \mathrm{kg})$. Results showed that larvae fed the diet with supplementation of $40 \mathrm{mg} / \mathrm{kg}$ FA had significantly higher survival rate, while the specific growth rate was significantly higher in larvae fed diets with 40 and $80 \mathrm{mg} / \mathrm{kg}$ FA than the control group $(P<0.05)$. Activities of trypsin in pancreatic segments (PS) and intestinal segments, lipase in PS and Alkaline phosphatase in brush border membrane were significantly increased by supplementation of FA compared to the control group $(P<0.05)$. Supplementation of FA significantly increased activities of total superoxide dismutase and catalase, and reduced the malondialdehyde content compared to the control group. Meanwhile, activities of lysozyme, total nitric oxide synthase and nitric oxide content were significantly improved by supplementation of FA in diets. Furthermore, results revealed that supplementation of FA reduced the lipid accumulation in visceral mass of larvae fed the diet with $40 \mathrm{mg} / \mathrm{kg}$ FA probably through inhibiting gens expression of lipogenesis-related genes ( $s c d 1$, fas and dgat2) and promoting expression of lipid catabolismrelated genes ( $a c 0, c p t 1$, and $h)$. In conclusion, appropriate supplementation of $40 \mathrm{mg} / \mathrm{kg}$ FA could improve the survival and growth performance of large yellow croaker larvae through increasing digestive, antioxidant capacity and promoting lipid metabolism.

\section{Introduction}

Ferulic acid (FA) is a hydroxycinnamic acid extracted from natural products, especially the Chinese herb Ferula sinkiangensis K. M. Shen (Silva and Batista 2017; Zhu et al. 2020). As a promising therapeutic phytochemical (Chaudhary et al. 2019), FA had been confirmed of a wide range of functions in regulating enzyme activities (Silva and Batista 2017), promoting abilities of anti-oxidation (Sarker and Oba 2020; Soobrattee et al. 2005), anti-inflammation (Zhou et al. 2020) and anti-cancer (Chaudhary et al. 2018; Middleton et al. 2000). In recent years, researches in the application of FA were carried out in aquatic animals. Previous studies have shown that supplementation of FA can improve the growth performance, antioxidant capacity and immune response of Nile tilapia (Oreochromis niloticus), and promote the development of digestive system by improving intestinal morphology and microbiome composition (Dawood et al. 2020; Yu et al. 2020a, b). Moreover, the supplementation of FA in diets enhanced the integument color and inhibited oxidative stress in Red Sea Bream (Pagrus major) (Maoka et al. 2008).

Large yellow croaker (Larimichthys crocea) is a carnivorous marine fish species which was widely cultured in southeast China due to delicious taste and commercial value (Feng et al. 2017). Compared with juvenile and adult fish, larval phase is critical to fulfill the development of organ systems of the physiological functions (Huang et al. 2020; Liu et al. 2020). However, the production of larvae is still hampered by high mortality during the metamorphosis and weaning (Yao et al. 2020). Nutritional studies on fish larvae had focused on feeding habits, digestive physiology and nutritional requirements (Ai et al. 2008; Feng et al. 2017; Zhao et al. 2013), while few studies on the promotion of larval survival and growth by Chinese herbs were published. 
Nevertheless, there was no report even concerned about activities of digestive enzyme and the lipid metabolism of supplementation of FA in marine fish larvae. Thus, the present study intended to evaluate the potential effects of supplementation of FA on growth performance, activities of digestive enzyme, antioxidant capacity and lipid metabolism of large yellow croaker larvae.

\section{Materials And Methods}

\section{Feed ingredients and diets formulation}

Four isonitrogenous ( $50.0 \%$ crude protein) and isoenergetic ( $16.7 \%$ crude lipid) micro-diets were formulated with graded levels of $F A(0,20,40$, and $80 \mathrm{mg} / \mathrm{kg}$ dry diet) (Table 1). The purity of FA was above $99.0 \%$, purchased from Beijing Solarbio Technology Co., Ltd in China. 
Table 1

Formulation and proximate analysis of the experimental diets (\% dry matter).

\begin{tabular}{|c|c|c|c|c|}
\hline \multirow[t]{2}{*}{ Ingredient \% dry diet } & \multicolumn{4}{|c|}{ Diets (Ferulic Acid \%) } \\
\hline & Diet1 (0) & Diet2 (20) & Diet3 (40) & Diet4 (80) \\
\hline White fish meal a & 45 & 45 & 45 & 45 \\
\hline Krill meal ${ }^{a}$ & 22 & 22 & 22 & 22 \\
\hline Squid viscera meal ${ }^{a}$ & 3 & 3 & 3 & 3 \\
\hline Yeast hydrolysate ${ }^{a}$ & 3.5 & 3.5 & 3.5 & 3.5 \\
\hline Soybean Lecithin ${ }^{b}$ & 5 & 5 & 5 & 5 \\
\hline a-starch & 2.9 & 2.9 & 2.9 & 2.9 \\
\hline Calcium bis & 2 & 2 & 2 & 2 \\
\hline Vitamin premix ${ }^{c}$ & 1.5 & 1.5 & 1.5 & 1.5 \\
\hline Mineral premix ${ }^{d}$ & 1 & 1 & 1 & 1 \\
\hline Ascorbyl polyphosphate & 0.2 & 0.2 & 0.2 & 0.2 \\
\hline Sodium alginate & 2 & 2 & 2 & 2 \\
\hline Mould inhibitor & 0.05 & 0.05 & 0.05 & 0.05 \\
\hline Antioxidant & 0.05 & 0.05 & 0.05 & 0.05 \\
\hline Choline choride & 0.2 & 0.2 & 0.2 & 0.2 \\
\hline Fish oil & 6.5 & 6.5 & 6.5 & 6.5 \\
\hline Strong flour & 5 & 5 & 5 & 5 \\
\hline Microcrystalline Cellulose & 0.1 & 0.098 & 0.096 & 0.092 \\
\hline Ferulic acid ${ }^{e}$ & 0 & 0.002 & 0.004 & 0.008 \\
\hline \multicolumn{5}{|c|}{ Analyzed nutrients composition (dry matter basis) } \\
\hline Crude protein (\%) & 49.92 & 50.11 & 50.30 & 50.37 \\
\hline Crude lipid (\%) & 16.83 & 16.84 & 16.89 & 16.70 \\
\hline \multicolumn{5}{|c|}{$\begin{array}{l}\text { a Commercially available from Great Seven Biotechnology Co., Ltd in Shandong, China; elementary } \\
\text { composition (dry matter): White fish meal, crude protein, } 71.73 \% \text {, crude lipid, } 4.76 \% \text {; Krill meal, crude } \\
\text { protein, } 64.86 \% \text {, crude lipid, } 8.0 \% \text {; Squid viscera meal, crude protein, } 81.81 \% \text {, crude lipid, } 5.16 \% \text {. }\end{array}$} \\
\hline
\end{tabular}


Diet1 (0) Diet2 (20) Diet3 (40) Diet4 (80)

${ }^{c}$ Composition of vitamin premix (IU or g kg${ }^{-1}$ ): vitamin A palmitate, $3000000 \mathrm{IU}$; vitamin $\mathrm{D}_{3}, 1200000 \mathrm{IU}$; DL-a-vitamin E, $40.0 \mathrm{~g} / \mathrm{kg}$; menadione, $8.0 \mathrm{~g} / \mathrm{kg}$; thiamine-HCl, $5.0 \mathrm{~g} / \mathrm{kg}$; riboflavin, $5.0 \mathrm{~g} / \mathrm{kg}$; D-calcium pantothenate, $16.0 \mathrm{mg} / \mathrm{kg}$; pyridoxine-HCl, $4.0 \mathrm{mg} / \mathrm{kg}$; inositol, $200.0 \mathrm{mg} / \mathrm{kg}$; biotin, $8.0 \mathrm{mg} / \mathrm{kg}$; folic acid, $1.5 \mathrm{mg} / \mathrm{kg}$; 4-aminobenzoic acid, $5.0 \mathrm{mg} / \mathrm{kg}$; niacin, $20.0 \mathrm{mg} / \mathrm{kg}$; vitamin $\mathrm{B}_{12}, 0.01 \mathrm{mg} / \mathrm{kg}$; L-ascorgyl-2monophosphate- $\mathrm{Na}(3 \%), 2000.0 \mathrm{mg} / \mathrm{kg}$.

${ }^{d}$ Composition of mineral premix (g/kg premix): $\mathrm{Ca}\left(\mathrm{H}_{2} \mathrm{PO}_{4}\right) \cdot \mathrm{H}_{2} \mathrm{O}, 675.0 ; \mathrm{C}_{0} \mathrm{SO}_{4} \cdot \mathrm{H}_{2} \mathrm{O}, 0.15 ; \mathrm{CuSO}_{4} \cdot \mathrm{H}_{2} \mathrm{O}, 5.0$; $\mathrm{FeSO}_{4} \cdot 7 \mathrm{H}_{2} \mathrm{O}, 50.0 ; \mathrm{KCl}, 0.1 ; \mathrm{MgSO}_{4} \cdot 2 \mathrm{H}_{2} \mathrm{O}, 101.7 ; \mathrm{MnSO}_{4} \cdot 2 \mathrm{H}_{2} \mathrm{O}, 18.0 ; \mathrm{NaCl}, 80.0 ; \mathrm{NaSeO}_{3} \cdot \mathrm{H}_{2} \mathrm{O}, 0.05$; $\mathrm{ZnSO}_{4} \cdot 7 \mathrm{H}_{2} \mathrm{O}, 20.0$.

e The ferulic acid was purchased from Beijing Solarbio Technology Co., Ltd in Beijing, China. The purity was $\geq 99.0 \%$.

Micro-diet was manufactured by extrusion-spheronization method using axial single screw spherical extruder and spheronization. All formulated diets were packed in separate silver bags and stored at $-20^{\circ} \mathrm{C}$ until use.

\section{Experimental procedures}

Disease-free, homogenous size of large yellow croaker larvae were supplied and reared at Marine and Fishery Science and Technology Innovation Base, Zhejiang, China. The average body weight of large yellow croaker larvae was $2.58 \pm 0.30 \mathrm{mg}$. All larvae were fed with rotifers (Brachionus plicatilis) $\left(0.5-1.5 \times 10^{4}\right.$ individual/L) from 3 to $8 \mathrm{DAH}$, brine shrimp (Artemia nauplii) (1.0-1.5 $\times 10^{3}$ individual/L) from 6 to $11 \mathrm{DAH}$, and the mix of live copepodas (Calanus sinicus) and the control feed of experiment from 10 to $14 \mathrm{DAH}$. Then all the larvae were completely fed with experimental diet. The experiment was carried out in 12 white plastic tanks with a water volume of $220 \mathrm{~L}$ and density of randomly selected 3000 larvae per tank. Four experimental diets were randomly allocated to triplicate groups of larvae. From 15 to $45 \mathrm{DAH}$, larvae were manually fed to satiation with the experimental diets seven times $(06: 30,09: 30,12: 30,15: 30,18: 30,21: 30$, and 23:30) daily. The seawater was filtered through the secondary sand filter and was changed 150-200\% daily. During the rearing period, water quality was controlled in temperature of $24.5 \pm 1.5^{\circ} \mathrm{C}, \mathrm{pH}$ of $8.0 \pm 0.2$ and salinity of $23 \pm 2 \mathrm{~g} / \mathrm{L}$.

\section{Sampling and dissection}

At the beginning of the experiment, initial body length (IBL) and initial body weight (IBW) were measured by fifty larvae of $15 \mathrm{DAH}$ collected randomly from each tank. At the termination, the survival rate (SR) was determined by counting the remaining individuals in each tank. All $45 \mathrm{DAH}$ larvae were fasting for $24 \mathrm{~h}$ at the end of the experiment to empty digestive tract, and then were sampled. Fifty individuals were randomly selected from each tank to monitor the final body length (FBL) and final body weight (FBW). Twenty larvae in each tank were dissected on ice to obtain visceral masses containing a crude mixture of pancreas, liver, heart, spleen, and intestine. The visceral masses were quickly put into $2.0 \mathrm{~mL}$ RNase-free cryogenic vials, then immediately frozen in liquid nitrogen for gene expression analysis. Fifty larvae were separated under a 
dissecting microscope on a glass plate maintained at $0{ }^{\circ} \mathrm{C}$ to obtain pancreatic segments (PS) and intestinal segments (IS) for the determination of activities of digestive enzyme.

\section{Body composition}

After sampling, remaining larvae were taken out from each tank to measure total crude protein, crude lipid, and moisture. The moisture content was determined by placing the sample in a ventilated drying oven at $105^{\circ} \mathrm{C}$ until the larval weight was constant. The crude protein and the crude lipid of the sample were determined following the method of Association with Official Analytical Chemists (AOAC 2003).

\section{Digestive enzyme activities assay}

Samples of 0.2-0.3 g PS and IS were homogenized in $2 \mathrm{~mL} 0{ }^{\circ} \mathrm{C}$ phosphate-buffered saline $(\mathrm{pH}=7.4)$ respectively and centrifuged at $3300 \mathrm{~g}$ for 10 mins. The supernatant was collected for further determination. Purified brush border membranes (BBM) from homogenate of the intestinal segment were obtained according to a method described by Crane et al. (1979). The activity of trypsin was assayed in accordance with Holm et al. (1988). The activity of leucine-aminopeptidase (LAP) was assayed according to Ji et al. (2013) and Maroux et al. (1973). Several assay kits including total protein quantitative assay kit, a-Amylase assay kit, lipase assay kit, and alkaline phosphatase (AKP) assay kit were purchased from Nanjing Jiancheng Institute of Biological Engineering, China. All experiments were carried out in strict accordance with the instructions.

\section{Antioxidant and innate immune enzyme activities assay}

The visceral mass of fish larvae was weighed and homogenized in $0{ }^{\circ} \mathrm{C}$ phosphate-buffered saline $(\mathrm{pH}=$ 7.4). The proportion of tissue $(\mathrm{g})$ and saline $(\mathrm{mL})$ was 1:9. The homogenate of visceral mass was then centrifuged at $3300 \mathrm{~g}$ for $10 \mathrm{mins}$, and the supernatant was used for the assay of activities of antioxidant and innate immune enzyme. Activities of total superoxide dismutase (T-SOD), total antioxidant capacity (TAOC) catalase (CAT), and Malondialdehyde (MDA) content as well as activities of lysozyme (LZ), total nitric oxide synthase (T-NOS), inducible nitric oxide synthase (iNOS) and nitric oxide (NO) content in visceral mass were determined by commercial reagents and kits (Nanjing Jiancheng Bio-Engineering Institute, China).

\section{RNA extraction and real-time quantitative PCR}

The sample was pulverized in liquid nitrogen and added with Trizol reagent (Takara, Japan). The total RNA was extracted according to the manufacturer's protocol. The integrity of RNA was evaluated by electrophoresis, and the total RNA concentration was measured using a Nano Drop® 2000 spectrophotometer (Thermo Fisher Scientific, USA). RNase-Free DNase (Takara, Japan) was using to remove the DNA contaminant in RNA. The RNA was reversely transcribed to cDNA by Prime Script-RT reagent Kit (Takara, Japan). The real-time quantitative polymerase chain reaction was carried out in a quantitative thermal cycler (CFX96TM Real-Time System, BIO-RAD, USA). The primers sequence of stearoylcoenzyme A desaturase 1 (scd1), fatty acid synthase (fas), diacylgycerol acyltransferase (dgat2), sterolregulatory element binding protein 1 (srebp 1), acyl-CoA oxidase (aco), carnitine palmitoyl transferase 1 (cpt1), peroxisome proliferators-activated receptor (ppara), hepatic lipase ( $h$ ), lipoprteinlipase (Ipl), fatty acid binding protein 3 (fabp3), fatty acid binding protein 10 (fabp 10), fatty acid binding protein 11 (fabp11), 
microsomal TAG transfer protein ( $m$ tp), apolipoprotein b100 (apob100) and $\beta$-actin, were synthesized based on the published sequences from Cai et al. (2017) Xu et al. (2015), Yan et al. (2015), and Zuo et al. (2013) (Table 2). Real-time quantitative PCR temperature profile was $95^{\circ} \mathrm{C}$ for 2 mins, followed by 39 cycles of 95 ${ }^{\circ} \mathrm{C}$ for $10 \mathrm{~s}, 59{ }^{\circ} \mathrm{C}$ for $10 \mathrm{~s}$, and $72{ }^{\circ} \mathrm{C}$ for $20 \mathrm{~s}$. The fluorescence data acquired during the extension phase were normalized to $\beta$-actin via $2^{-\triangle \Delta C T}$ methods as described by Livak and Schmittgen (2001). 
Table 2

Primers used for quantitative PCR.

\begin{tabular}{|c|c|c|c|}
\hline Gene & Forward(5'-3') & Reverse( $\left.5^{\prime}-3^{\prime}\right)$ & $\begin{array}{l}\text { Accession } \\
\text { number }\end{array}$ \\
\hline scd1 & AAAGGACGCAAGCTGGAACT & CTGGGACGAAGTACGACACC & $\begin{array}{l}\text { Xu et al. } \\
\text { (2015) }\end{array}$ \\
\hline fas & CAGCCACAGTGAGGTCATCC & TGAGGACATTGAGCCAGACAC & $\begin{array}{l}\text { Cai et al. } \\
\text { (2017) }\end{array}$ \\
\hline dgat2 & TTCGGTGCTTTCTGCAACTTCG & AAGGATGGGGAAGCGGAAGT & $\begin{array}{l}\text { Yan et al. } \\
(2015)\end{array}$ \\
\hline srebp 1 & TCTCCTTGCAGTCTGAGCCAAC & TGAGGACATTGAGCCAGACAC & $\begin{array}{l}\text { Cai et al. } \\
\text { (2017) }\end{array}$ \\
\hline aco & AGTGCCCAGATGATCTTGAAGC & CTGCCAGAGGTAACCATTTCCT & $\begin{array}{l}\text { Yan et al. } \\
(2015)\end{array}$ \\
\hline$c p t 1$ & GCTGAGCCTGGTGAAGATGTTC & TCCATTTGGTTGAATTGTTTACTGTCC & $\begin{array}{l}\text { Yan et al. } \\
\text { (2015) }\end{array}$ \\
\hline ppara & GTCAAGCAGATCCACGAAGCC & TGGTCTTTCCAGTGAGTATGAGCC & $\begin{array}{l}\text { Zuo et al. } \\
(2013)\end{array}$ \\
\hline$h l$ & TCCGTCCATCTATTCATTGACTCTC & GCCACTGTGAACCTTCTTGATATTG & $\begin{array}{l}\text { Cai et al. } \\
\text { (2017) }\end{array}$ \\
\hline$|p|$ & GAGAGGATTCATCTGCTGGGTTAC & ACATCAACAAACTGGGCGTCATC & $\begin{array}{l}\text { Yan et al. } \\
(2015)\end{array}$ \\
\hline fabp3 & ССАААСССАССАСТАТСАТСТСАG & GCACСАTСTTTСССТССТСТАTTG & $\begin{array}{l}\text { Yan et al. } \\
(2015)\end{array}$ \\
\hline fabp10 & CAATGGAACATGGCAGGTTTACG & TGATTGGCTTGATGTCCTTGGC & $\begin{array}{l}\text { Yan et al. } \\
\text { (2015) }\end{array}$ \\
\hline fabp 11 & CAGGTGGGCAATCGGACCAA & GGCTCGTTGAGCTTGAACTTGA & $\begin{array}{l}\text { Yan et al. } \\
\text { (2015) }\end{array}$ \\
\hline$m t p$ & ATGTCCAAAATGTTCTCCATGTCTG & ATGTCAATAGCCAACCCTCCTTG & $\begin{array}{l}\text { Cai et al. } \\
\text { (2017) }\end{array}$ \\
\hline apob100 & AGAGTGTTGTCCAGGATAAAGATGC & CAGGGCTCAGGGTCTCAGTC & $\begin{array}{l}\text { Cai et al. } \\
\text { (2017) }\end{array}$ \\
\hline$\beta$-actin & GACCTGACAGACTACCTCATG & AGTTGAAGGTGGTCTCGTGGA & $\begin{array}{l}\text { Yan et al. } \\
(2015)\end{array}$ \\
\hline \multicolumn{4}{|c|}{$\begin{array}{l}\text { scd1, stearoyl-CoA desaturase } 1 \text {; fas, fatty acid synthase; dgat2, diacylgycerol acyltransferase 2; srebp 1, } \\
\text { sterol-regulatory element binding protein } 1 \text {; aco, acyl-CoA oxidase; } c p t-1 \text {, carnitine palmitoyl transferase- } \\
\text { 1; ppara, peroxisome proliferators-activated receptor; } h \text { l, hepatic lipase; Ipl, lipoprtein lipase; fabp3, fatty } \\
\text { acid binding protein 3; fabp 10, fatty acid binding protein 10; fabp 11, fatty acid binding protein 11; mtp, } \\
\text { microsomal TAG transfer protein; apob } 100 \text {, apolipoprotein b100. }\end{array}$} \\
\hline
\end{tabular}

\section{Calculations and statisticasl analysis}


The parameters were calculated as follows:

Survival rate $(S R, \%)=N_{t} \times 100 / N_{0}$

Specific growth rate $(S G R, \% /$ day $)=\left(\operatorname{Ln~W}_{t}-\operatorname{Ln~} W_{0}\right) \times 100 / d$

where $N_{t}$ is the final number of larvae in each tank, and $N_{0}$ is the initial number of larvae in each tank; $W_{t}$ is the final wet body weight $(\mathrm{g})$, and $\mathrm{W}_{0}$ is the initial wet body weight; $d$ is the experimental period in days.

All data were subjected to perform statistical analysis by using SPSS Statistics 25.0 software (SPSS Inc., USA). The data were firstly analyzed by using one-way analysis of variance (ANOVA), and then determined by Tukey's multiple range test. The level of significance was chosen at $P<0.05$. Results were expressed as mean \pm S.E.M. (Standard error of means).

\section{Results}

\section{Survival, growth performance and body composition}

With the supplementation of FA increasing from 0 to $40 \mathrm{mg} / \mathrm{kg}$, the SR of large yellow croaker larvae significantly increased from 15.50 to $21.42 \%(P<0.05)$ (Table 3). Meanwhile, larvae fed the diet with 40 and $80 \mathrm{mg} / \mathrm{kg}$ FA showed significantly higher SGR than the control group $(P<0.05)$ (Table 3$)$. The crude protein of larvae showed an increasing trend, while the total lipid was decreasing from 20.45 to $19.32 \%$ with FA supplementation from 0 to $20 \mathrm{mg} / \mathrm{kg}$, but no significant differences were observed among dietary treatments $(P>0.05)$ (Table 4). 
Table 3

Effects of supplementation of ferulic acid (FA) on survival and growth performance of large yellow croaker larvae (Means \pm S.E.M., $n=3)^{1}$.

\begin{tabular}{|c|c|c|c|c|}
\hline \multirow[t]{2}{*}{ Parameters } & \multicolumn{4}{|c|}{ Diets (Ferulic acid supplementation level mg/kg) } \\
\hline & Diet1 (0) & Diet2 (20) & Diet3 (40) & Diet4 (80) \\
\hline $\begin{array}{l}\text { Final body length } \\
\text { (FBL, mm) }\end{array}$ & $16.47 \pm 0.32$ & $18.31 \pm 0.32$ & $18.69 \pm 0.93$ & $18.65 \pm 1.34$ \\
\hline $\begin{array}{l}\text { Final body weight } \\
\text { (FBW, mg) }\end{array}$ & $80.21 \pm 6.05^{b}$ & $108.18 \pm 7.72^{\mathrm{ab}}$ & $124.81 \pm 6.14^{\mathrm{a}}$ & $121.76 \pm 8.93^{a}$ \\
\hline $\begin{array}{l}\text { Specific growth rate } \\
\text { (SGR \%/day) }\end{array}$ & $11.44 \pm 0.24^{b}$ & $12.57 \pm 0.20^{\mathrm{ab}}$ & $12.87 \pm 0.43^{a}$ & $12.83 \pm 0.24^{a}$ \\
\hline Survival rate & $15.50 \pm 1.16^{\mathrm{b}}$ & $16.44 \pm 0.34^{\mathrm{ab}}$ & $21.42 \pm 1.29^{a}$ & $18.72 \pm 1.69^{a b}$ \\
\hline$(\mathrm{SR} \%)$ & & & & \\
\hline
\end{tabular}

Table 4

Effects of supplementation of ferulic acid (FA) on body composition in large yellow croaker (Larmichthys crocea) larvae. (Means \pm S.E.M., $\mathrm{n}=3)^{1}$.

\begin{tabular}{|lllll|}
\hline Parameters & \multicolumn{4}{l}{ Diets (Ferulic acid supplementation level mg/kg) } \\
\cline { 2 - 5 } & Diet1 (0) & Diet2 (20) & Diet3 (40) & Diet4 (80) \\
\hline Crude protein (\%) & $57.91 \pm 0.38$ & $58.20 \pm 0.92$ & $59.11 \pm 0.72$ & $58.74 \pm 0.77$ \\
\hline Crude lipid (\%) & $20.45 \pm 0.19$ & $19.32 \pm 0.43$ & $19.53 \pm 0.73$ & $19.91 \pm 0.48$ \\
\hline Moisture (\%) & $87.79 \pm 0.34$ & $88.39 \pm 1.02$ & $88.78 \pm 0.81$ & $90.69 \pm 0.48$ \\
\hline $\begin{array}{l}\text { 1 Data are presented as means } \pm \text { S.E.M. Means in each row sharing the same superscript letter or } \\
\text { absence of superscripts are not significantly different determined by Tukey's test }(P>0.05) \text {. S.E.M.: } \\
\text { standard error of means. }\end{array}$ \\
\hline
\end{tabular}

\section{Activities of digestive enzyme}


No significant difference in the activity of amylase in larval PS and IS were observed among all dietary treatments $(P>0.05)$ (Table 5). The activity of trypsin in PS of larvae fed the diet with $20 \mathrm{mg} / \mathrm{kg} \mathrm{FA}$ and trypsin in IS in larvae fed diets with 20 and $40 \mathrm{mg} / \mathrm{kg}$ FA were significantly higher than the control group $(P<$ 0.05 ) (Table 5). Meanwhile, the activity of lipase in larval PS were significantly higher in larvae fed diets with 20 and $40 \mathrm{mg} / \mathrm{kg}$ FA than the control group $(P<0.05)$ (Table 5). The activity of AKP in BBM of larvae fed diets with 20 and $40 \mathrm{mg} / \mathrm{kg}$ FA had significantly higher activities compared to the control group $(P<0.05)$, while no difference was observed among dietary treatments in LAP of larvae BBM $(P>0.05)$ (Table 5$)$.

Table 5

Effects of supplementation of ferulic acid (FA) on activities of main digestive enzymes of large yellow croaker larvae (Means \pm S.E.M., $\mathrm{n}=3)^{1}$.

\begin{tabular}{|c|c|c|c|c|c|}
\hline \multirow[t]{2}{*}{ Parameters } & & \multicolumn{4}{|c|}{ Diets (Ferulic acid supplementation level $\mathrm{mg} / \mathrm{kg}$ ) } \\
\hline & & Diet1 (0) & Diet2 (20) & Diet3 (40) & Diet4 (80) \\
\hline \multirow{2}{*}{$\begin{array}{l}\text { Amylase } \\
\text { (U/mg·protein) }\end{array}$} & PS & $0.30 \pm 0.04$ & $0.35 \pm 0.02$ & $0.24 \pm 0.04$ & $0.29 \pm 0.01$ \\
\hline & IS & $0.27 \pm 0.03$ & $0.26 \pm 0.02$ & $0.24 \pm 0.04$ & $0.28 \pm 0.03$ \\
\hline \multirow{2}{*}{$\begin{array}{l}\text { Trypsin } \\
\text { (U/mg·protein) }\end{array}$} & PS & $0.45 \pm 0.12^{b}$ & $0.93 \pm 0.10^{\mathrm{a}}$ & $0.82 \pm 0.12^{\mathrm{ab}}$ & $0.44 \pm 0.37^{b}$ \\
\hline & IS & $1.07 \pm 0.13^{b}$ & $2.03 \pm 0.12^{\mathrm{a}}$ & $1.85 \pm 0.12^{\mathrm{a}}$ & $1.62 \pm 0.18^{\mathrm{ab}}$ \\
\hline \multirow{2}{*}{$\begin{array}{l}\text { Lipase } \\
\text { (mU/mg·protein) }\end{array}$} & PS & $0.97 \pm 0.10^{b}$ & $1.50 \pm 0.10^{\mathrm{a}}$ & $1.50 \pm 0.08^{\mathrm{a}}$ & $1.28 \pm 0.11^{\mathrm{ab}}$ \\
\hline & IS & $0.98 \pm 0.21$ & $1.32 \pm 0.12$ & $1.64 \pm 0.23$ & $1.25 \pm 0.16$ \\
\hline $\begin{array}{l}\text { AKP } \\
\text { (U/mg·protein) }\end{array}$ & BBM & $1.05 \pm 0.06^{b}$ & $1.72 \pm 0.15^{\mathrm{a}}$ & $1.66 \pm 0.14^{\mathrm{a}}$ & $1.35 \pm 0.22^{\mathrm{ab}}$ \\
\hline $\begin{array}{l}\text { LAP } \\
\text { (U/mg·protein) }\end{array}$ & BBM & $12.17 \pm 0.55$ & $13.24 \pm 0.63$ & $13.43 \pm 1.73$ & $14.74 \pm 0.86$ \\
\hline
\end{tabular}

Abbreviations: AKP, Alkaline-phosphatase; LAP, Leucine-aminopeptidase; PS, Pancreatic segments; IS, Intestinal segments; BBM: brush border membranes.

1. Data are presented as means \pm S.E.M. Means in each row sharing the same superscript letter or absence of superscripts are not significantly different determined by Tukey's test $(P>0.05)$. S.E.M.: standard error of means.

\section{Antioxidant and innate immunity capacity}

The activity of T-SOD was significantly higher in larvae fed the diet with $40 \mathrm{mg} / \mathrm{kg}$ FA compared to the control group $(P<0.05)$ (Fig. 1A). However, the activity of T-AOC was not significantly different among dietary treatments $(P>0.05)$ (Fig. 1B). The activity of CAT in larvae fed diets with 20 and $40 \mathrm{mg} / \mathrm{kg}$ FA was significantly higher than the control group $(P<0.05)$ (Fig. 1C). Meanwhile, the MDA content in larvae fed diets with 20 and $40 \mathrm{mg} / \mathrm{kg}$ FA were significantly lower than the control group $(P<0.05)$ (Fig. 1D). The 
activity of LZ in visceral mass was significantly higher in larvae fed diets with 20 and $40 \mathrm{mg} / \mathrm{kg}$ FA than the control group $(P<0.05)$ (Fig. 2A), while larvae fed the diet with $40 \mathrm{mg} / \mathrm{kg}$ FA had the significantly higher activity of T-NOS compared to the control group $(P<0.05)$ (Fig. 2B). No significant difference was observed in the activity of iNOS among dietary treatments $(P<0.05)$ (Fig. 2C). The NO content in larvae fed diets with 40 and $80 \mathrm{mg} / \mathrm{kg}$ FA were significantly higher than the control group $(P<0.05)$ (Fig. 2D).

\section{Triglyceride (TG) content and mRNA expression of lipid metabolism-related genes in visceral mass}

TG content of visceral mass in larvae fed the diet with $40 \mathrm{mg} / \mathrm{kg}$ FA was significantly lower than the other groups $(P<0.05)$ (Fig. 3A). In terms of the lipogenesis-related mRNA expression, mRNA expression of $s c d 1$ and fas were significantly lower in larvae fed the diet with $80 \mathrm{mg} / \mathrm{kg}$ FA than the control group $(P<0.05)$, while supplementation of $40 \mathrm{mg} / \mathrm{kg}$ FA significantly reduced the mRNA expression of dgat2 $(P<0.05)$ (Fig. 3B). For the fatty acid catabolism-related genes expression, compared to the control group, larvae fed the diet with $80 \mathrm{mg} / \mathrm{kg}$ FA had significantly higher mRNA expression of aco, and larvae fed diets with 40 and $80 \mathrm{mg} / \mathrm{kg}$ FA had significantly higher mRNA expression of $c p t 1$ and $h /(P<0.05)$ (Fig. 3C). No significant difference was found in the mRNA expression of ppara and $/ p /$ among all treatments $(P>0.05)$ (Fig. 3C). For the lipid transport-related genes, the mRNA expression of fabp3 was significantly lower in larvae fed diets with 20 and $80 \mathrm{mg} / \mathrm{kg} \mathrm{FA}(P<0.05)$ and the mRNA expression of fabp 11 was significantly reduced by supplementation of 20 and $40 \mathrm{mg} / \mathrm{kg} \mathrm{FA}(P<0.05)$ compared to the control group (Fig. 3D). Larvae fed the diet with $40 \mathrm{mg} / \mathrm{kg}$ FA had significantly higher fatp 1 expression than the control group ( $P<$ 0.05) (Fig. 3D). No significant differences was found in the mRNA expression of $m t p$, fabp10 and apob100 among all dietary treatments $(P>0.05)$ (Fig. 3D).

\section{Discussion}

Results of the present study demonstrated that the survival and growth performance of large yellow croaker larvae were significantly enhanced by supplementation of $40 \mathrm{mg} / \mathrm{kg} \mathrm{FA}$, which was consistent with previous findings of farm livestocks in lambs (Macías-Cruz et al. 2014; Valadez-García et al. 2021), heifers (PenaTorres et al. 2021), weaned piglets (Wang et al. 2020), and fish in Nile tilapia (Dawood et al. 2020; Yu et al. 2020a, b), and zebrafish (Danio rerio) (Wen and Ushi 2017). These researches demonstrated that supplementation of dietary FA could promote the survival and growth performance of large yellow croaker larvae, which were probably due to its improvement in the activities of digestive enzyme, anti-oxidation capacity and lipid metabolism.

Improving the activity of digestive enzyme generally led to the advancement efficiency of nutrient digestion and absorption, and then enhance digestive system function of fish larvae (Izquierdo et al. 2000; Khoa et al. 2021). Previous studies have found that enhancing digestive enzyme activities can promote the survival and growth of fish larvae (Imentai et al. 2020), which was similar to the results of the present study. AKP, concentrated in BBM, is an important indicator of digestive and absorptive functions of the intestine (Yuan et al. 2020). In the present study, FA in diets not only improved the activity of trypsin (PS and IS) and lipase 
(PS), but also significantly improved activities of AKP (BBM), indicating the improvement of digest ability of large yellow croaker larvae. These results indicated that FA could improve activities of digestive enzymes of large yellow croaker larvae, which were consistent with the results in Nile tilapia (Yu et al. 2020b).

The antioxidant function of fish larvae is not mature, which made the larvae susceptible to the influence of external environment and resulted in slower growth (Birnie-Gauvin et al. 2017). Various kinds of stresses may trigger the production of reactive oxygen species (ROS), then cause oxidative injuries such as lipid peroxidation and DNA damage (Martínez-Álvarez et al. 2005). In order to cope with the stresses, antioxidant defenses system has been developed, containing T-SOD, CAT, and T-AOC (Martínez-Álvarez and Morales 2005). In the present study, activities of SOD and CAT in larvae fed diets with FA were significantly higher than the control group. The result was similar to the study in Nile tilapia (Yu et al. 2016, 2020a), which found that the supplementation of dietary FA could decrease the MDA content and increase activities of SOD and CAT. MDA is the biomarker of oxidative damage (Del et al. 2005). In the present study, MDA content in larvae fed diets with 20 and $40 \mathrm{mg} / \mathrm{kg}$ FA were significantly decreased compared to the control group, suggesting that FA reduced the oxidative damage of large yellow croaker larvae. Also, Maoka et al. (2008) reached a similar conclusion that the addition of dietary FA significantly reduced the hepatic MDA content of Red Sea Bream. Therefore, diets supplemented with 20 to $40 \mathrm{mg} / \mathrm{kg}$ FA could enhance the antioxidant capacity of large yellow croaker larvae by increasing activities of antioxidant enzymes and reducing the damage of oxygen free radicals.

Antioxidant capacity was positively correlated with reduced inflammation (Li et al. 2019; Mukherjee et al. 2013). Herbal extract have been shown a positive effect on the immunity of fish (Giri et al. 2019; Nootash et al. 2013; Wang et al. 2015; Zemheri-Navruz et al. 2019). The promotion of non-specific immune system not only can help fish to overcome infectious factors but also has an important preventative role (Galina et al. 2009; Punitha et al. 2008; Reverter et al. 2014). The immune function of FA had already been shown in rats (Katayama et al. 2017; Sadar et al. 2016; Zheng et al. 2019) and carp (Cyprinus carpio) (Ahmadifar et al. 2019). In the present study, FA in diets significantly increased activities of LZ, T-NOS, and NO content of large yellow croaker larvae. Results were similarly to the Nile tilapia, which significantly enhanced the activity of LZ and NO content (Yu et al. 2020a). The obtained result in this study indicated the potential effect of FA in large yellow croaker larvae on enhancement of immunity and inhibition of stress, similar to the previous study in Nile tilapia (Dawood et al. 2020).

Due to high energy consumption of larvae, promoting lipid catabolism would supply more energy and spare more protein to increase the growth performance (Li et al. 2016). According to previous researches, FA had shown its excellent function on improving lipid metabolism in mammals (Koh et al. 2017; Guo et al. 2019; Wang et al. 2020; Wang et al. 2019) and fish (Yu et al. 2016). In the present study, the supplementation of $40 \mathrm{mg} / \mathrm{kg}$ FA had significantly reduced TG content in visceral mass, which was similar to the results in the Nile tilapia (Yu et al. 2016). The results indicated that FA could reduce the lipid accumulation of fish (Cohen et al. 2011). The mRNA expression of $s c d 1$, fas and dgat2 were significantly down-regulated by supplementation of FA compared to the control group. Scd1, fas and dgat2 are crucial in the process of adipocyte synthesis, indicating that FA could decrease the lipogenesis of large yellow croaker larvae (Carobbio et al. 2013; Harris et al. 2011). Compared with the control group, supplementation of FA activated 
aco, cpt1 and $h /$ genes thereby activating fatty acid oxidation and accelerating the lipid consumption process. The result was similar in mice with Ma et al. (2019). The mRNA expression of fabp3 and fabp11 in larvae fed diets with FA were markedly decreased compared to the control group. Results above showed that FA could reduce the lipogenesis and accumulation of large yellow croaker larvae, which was achieved by reducing the expression of lipogenesis-related genes, up-regulating the expression of lipid catabolismrelated genes and down-regulating the relative expression of transport-related genes. Combined with the growth of large yellow croaker larvae in this study, we have reason to suspect that supplementation of FA in diets can promote the SR and SGR of large yellow croaker larvae through improving the lipid metabolism of larvae.

\section{Conclusions}

In conclusion, results of the present study demonstrated that appropriate supplementation of FA ( $40 \mathrm{mg} / \mathrm{kg})$ could promote growth performance of large yellow croaker larvae, which was probably due to its improvement in activities of digestive enzymes, antioxidant capacity and lipid metabolism.

\section{Declarations}

\section{Funding}

This research was supported by the China Agriculture Research System (CARS47-11), Leading Talent of Technological Innovation of Ten-Thousands Talents Program (CS31117200001), and the Key Technology Research and Development Program of Shandong (CN) (No. 2019JZZY010814).

\section{Competing Interests}

The authors have no relevant financial or non-financial interests to disclose.

\section{Author contribution}

The authors' contributions were as follows: Q. A. and K. M. formulating the research question; W. X., W. H., C. Y., Y. L. and Z. Y. designed the study and conducted the research; W. X. analysed the data, interpreted the findings and wrote the article. All authors revised the article. We appreciate W. L., X. C., Y. G., and D. X. for their help in revising the article.

\section{Data Availability}

The datasets generated during and/or analyzed during the current study are available from the corresponding author on reasonable request

\section{Code availability}

Not applicable. 


\section{Consent to participate}

The authors agree to collaborate and publish this article.

\section{Ethics approval}

All experiments in this study were in accordance with the Management Rule of Laboratory Animals (Chinese Order No. 676 of the State Council, revised 1 March 2017).

\section{Consent for publication}

We will transfer the copyright of the article to editorial office for publishing.

\section{References}

1. Ahmadifar E, Moghadam MS, Dawood MAO, Hoseinifar SH (2019) Lactobacillus fermentum and/or ferulic acid improved the immune responses, antioxidative defence and resistance against Aeromonas hydrophila in common carp (Cyprinus carpio) fingerlings. Fish Shellfish Immunol 94:916-923. https://doi.org/10.1016/j.fsi.2019.10.019

2. Ai QH, Zhao JZ, Mai KS, Xu W, Tan BP, Ma HM, Liufu ZG (2008) Optimal dietary lipid level for large yellow croaker (Larimichthys crocea) larvae. Aquac Nutr 14:515-522. https://doi.org/10.1111/j.13652095.2007.00557.x

3. AOAC (2003) Official methods of analysis of the association of analytical chemistry, 15th edn. AOAC, Arlington, VA, USA

4. Birnie-Gauvin K, Costantini D, Cooke SJ, Cooke SJ, Willmore WG (2017) A comparative and evolutionary approach to oxidative stress in fish: A review. Fish Fish 18:928-942. https://doi.org/10.1111/faf.12215

5. Cai ZN, Mai KS, Ai QH (2017) Regulation of hepatic lipid deposition by phospholipid in large yellow croaker. Br J Nutr 118:999-1009. https://doi.org/10.1017/S000711451700294X

6. Carobbio S, Hagen RM, Lelliott CJ, Tan CY, Virtue S, Oresic M, Griffin JL, Sethi JK, Lopez M, Vidal-Puig A (2013) Adaptive changes of the Insig1/SREBP1/ SCD1 set point help adipose tissue to cope with increased storage demands of obesity. Diabetes 62:3697-3708. https://doi.org/10.2337/db12-1748

7. Chaudhary A, Choudhary S, Sharma U, Vig AP, Singh B, Arora S (2018) Purple head broccoli (Brassica oleracea L. var. italica Plenck), a functional food crop for antioxidant and anticancer potential. J Food Sci Technol (New Delhi, India) 55:1806-1815. https://doi.org/10.1007/s13197-018-3095-0

8. Chaudhary A, Jaswal VS, Choudhary S, Sonika, Sharma A, Beniwal V, Tuli HS, Sharma S (2019) Ferulic Acid: A promising therapeutic phytochemical and recent patents advances. Recent Pat Inflammation Allergy Drug Discovery 13:115-123. https://doi.org/10.2174/1872213X13666190621125048

9. Cohen JC, Horton JD, Hobbs HH (2011) Human fatty liver disease: Old questions and new insights. Science 332:1519-1523. https://doi.org/10.1126/science.1204265

10. Crane RK, Boge G, Rigal A (1979) Isolation of brush border membranes in vesicular form from the intestinal spiral valve of the small dogfish (Scyliorhinus canicula). Biochim Biophys Acta 554:264-267. 
https://doi.org/10.1016/0005-2736(79)90024-5

11. Dawood MAO, Metwally AS, El-Sharawy ME, Ghozlan AM, Abdel-Latif HMR, Van Doan H, Ali MAM (2020) The influences of ferulic acid on the growth performance, haemato-immunological responses, and immune-related genes of Nile tilapia (Oreochromis niloticus) exposed to heat stress. Aquaculture 525:735320. https://doi.org/10.1016/j.aquaculture.2020.735320

12. Del RD, Stewart AJ, Pellegrini N (2005) A review of recent studies on malondialdehyde as toxic molecule and biological marker of oxidative stress. Nutr Metab Cardiovasc Dis 15:316-328. https://doi.org/10.1016/j.numecd.2005.05.003

13. Feng SH, Cai ZN, Zuo RT, Mai KS, Ai QH (2017) Effects of dietary phospholipids on growth performance and expression of key genes involved in phosphatidylcholine metabolism in larval and juvenile large yellow croaker (Larimichthys crocea). Aquaculture 469:59-66. https://doi.org/10.1016/j.aquaculture.2016.12.002

14. Galina J, Yin G, Ardo L, Jeney Z (2009) The use of immunostimulating herbs in fish: An overview of research. Fish Physiol Biochem 35:669-676. https://doi.org/10.1007/s10695-009-9304-z

15. Giri SS, Sukumaran V, Park SC (2019) Effects of bioactive substance from turmeric on growth, skin mucosal immunity and antioxidant factors in common carp, Cyprinus carpio. Fish Shellfish Immunol 92:612-620. https://doi.org/10.1016/j.fsi.2019.06.053

16. Guo XX, Zeng Z, Qian YZ, Qiu J, Wang K, Wang Y, Ji BP, Zhou F (2019) Wheat flour, enriched with Yoryzanol, phytosterol, and ferulic acid, alleviates lipid and glucose metabolism in high-fat-fructose-fed rats. Nutrients 11:1697. https://doi.org/10.3390/nu11071697

17. Harris CA, Haas JT, Streeper RS, Stone SJ, Kumari M, Yang K, Han XL, Brownell N, Gross RW, Zechner R, Farese RV (2011) DGAT enzymes are required for triacylglycerol synthesis and lipid droplets in adipocytes. J Lipid Res 52:657-667. https://doi.org/10.1194/jlr.M013003

18. Holm H, Hanssen LE, Krogdahl A, Florholmen J (1988) High and low inhibitor soybean meals affect human duodenal proteinase activity differently in vivo comparison with bovine serum albumin. J Nutr 118:515-520. https://doi.org/10.1093/jn/118.4.515

19. Huang WX, Yao CW, Liu YT, Xu N, Yin ZY, Xu WX, Miao YQ, Mai KS, Ai QH (2020) Dietary allicin improved the survival and growth of Large Yellow Croaker (Larimichthys crocea) larvae via promoting intestinal development, alleviating inflammation and enhancing appetite. Front Physiol 11:587674. https://doi.org/10.3389/fphys.2020.587674

20. Imentai A, Rašković B, Steinbach C, Rahimnejad S, Yanes-Roca C, Policar T (2020) Effects of first feeding regime on growth performance, survival rate and development of digestive system in pikeperch (Sander lucioperca) larvae. Aquaculture 529:735636. https://doi.org/10.1016/j.aquaculture.2020.735636

21. Izquierdo MS, Socorro J, Arantzamendi L, Hernandez-Cruz CM (2000) Recent advances in lipid nutrition in fish larvae. Fish Physiol Biochem 22:97-107. https://doi.org/10.1023/A:1007810506259

22. Ji M, Yao LY, Zhang JH (2013) Continuous monitoring assay for leucine aminopeptidase in serum and its clinical value. Guide China Med 319:7. https://doi.org/10.15912/j.cnki.gocm.2013.07.116 
23. Katayama S, Ohno F, Mitani T, Akiyama H, Nakamura S (2017) Rutinosylated Ferulic Acid Attenuates Food Allergic Response and Colitis by Upregulating Regulatory T Cells in Mouse Models. J Agric Food Chem 65:10730-10737. https://doi.org/10.1021/acs.jafc.7b03933

24. Khoa TND, Hayasaka O, Matsui H, Waqalevu V, Honda A, Nakajima K, Yamashita H, Ishikawa M, Shiozaki K, Kotani T (2021) Changes in early digestive tract morphology, enzyme expression and activity of Kawakawa tuna (Euthynnus affinis). Aquaculture 530:735-935.

https://doi.org/10.1016/j.aquaculture.2020.735935

25. Koh EJ, Kim KJ, Seo YJ, Choi J, Lee BY (2017) Modulation of HO-1 by ferulic acid attenuates adipocyte differentiation in 3T3-L1 Cells. Molecules 22:745. https://doi.org/10.3390/molecules22050745

26. Li LY, Stasiak M, Li L, Xie BZ, Fu YM, Gidzinski D, Dixon MK, Liu H (2016) Rearing Tenebrio molitor in BLSS: Dietary fiber affects larval growth, development, and respiration characteristics. Acta Astronaut 118:130-136. https://doi.org/10.1016/j.actaastro.2015.10.003

27. Li XS, Ji RL, Cui K, Chen QC, Chen Q, Fang W, Mai KS, Zhang YJ, Xu WQ, Ai QH (2019) High percentage of dietary palm oil suppressed growth and antioxidant capacity and induced the inflammation by activation of TLR-NF-KB signaling pathway in large yellow croaker (Larimichthys crocea). Fish Shellfish Immunol 87:600-608. https://doi.org/10.1016/j.fsi.2019.01.055

28. Liu YT, Miao YQ, Xu N, Ding T, Cui K, Chen QC, Zhang JZ, Fang W, Mai KS, Ai QH (2020) Effects of dietary Astragalus polysaccharides (APS) on survival, growth performance, activities of digestive enzyme, antioxidant responses and intestinal development of large yellow croaker (Larimichthys crocea) larvae. Aquaculture 517:734752. https://doi.org/10.1016/j.aquaculture.2019.734752

29. Livak KJ, Schmittgen TD (2001) Analysis of relative gene expression data using real-time quantitative PCR and the 2- $\Delta \Delta C T$ method. Methods 25:402-408. https://doi.org/10.1006/meth.2001.1262

30. Management Rule of Laboratory Animals (Chinese Order No. 676 of the State Council, revised 1 March 2017). http://www.gov.cn/gongbao/content/2017/content_5219148.htm

31. Ma YC, Chen K, Lv L, Wu SY, Guo ZJ (2019) Ferulic acid ameliorates nonalcoholic fatty liver disease and modulates the gut microbiota composition in high-fat diet fed ApoE mice. Biomed Pharmacother 113:108753. https://doi.org/10.1016/j.biopha.2019.108753

32. Macías-Cruz U, Perard S, Vicente R, Alvarez FD, Torrentera-Olivera NG, Gonzalez-Rios H, Soto-Navarro SA, Rojo R, Meza-Herrera CA, Avendano-Reyes L (2014) Effects of free ferulic acid on productive performance, blood metabolites, and carcass characteristics of feedlot finishing ewe lambs. J Anim Sci 92:5762-5768. https://doi.org/10.2527/jas.2014-8208

33. Maoka T, Tanimoto F, Sano M, Tsurukawa K, Tsuno T, Tsujiwaki S, Ishimaru K, Takii K (2008) Effects of dietary supplementation of ferulic acid and gamma-oryzanol on integument color and suppression of oxidative stress in cultured red sea bream (Pagrus major). J Oleo Sci 57:133-137. https://doi.org/10.5650/jos.57.133

34. Maroux S, Louvard D, Barath J (1973) The aminopeptidase from hog intestinal brush border. Biochim Biophys Acta (BBA)-Enzymol 321:282-295. https://doi.org/10.1016/0005-2744(73)90083-1

35. Martínez-Álvarez RM, Morales AE, Sanz A (2005) Antioxidant defenses in fish: Biotic and abiotic factors. Rev : Methods Technol Fish Biol Fish 15:75-88. https://doi.org/10.1007/s11160-005-7846-4 
36. Middleton E, Kandaswami C, Theoharides TC (2000) The effects of plants flavonoids on mammalian cells: Implication for inflammation, heart diseases and cancer. Pharmacol Rev 52:673-751. https://doi.org/10.1006/phrs.2000.0734

37. Mukherjee S, Ghosh S, Choudhury S, Adhikary A, Manna K, Dey S, Sa G, Das T, Chattopadhyay S (2013) Pomegranate reverses methotrexate-induced oxidative stress and apoptosis in hepatocytes by modulating Nrf2-NF-KB pathways. J Nutr Biochem 24:2040-2050. https://doi.org/10.1016/j.jnutbio.2013.07.005

38. Nootash S, Sheikhzadeh N, Baradaran B, Oushani AK, Moghadam MRM, Nofouzi K, Monfaredan A, Aghebati L, Zare F, Shabanzadeh S (2013) Green tea (Camellia sinensis) administration induces expression of immune relevant genes and biochemical parameters in rainbow trout (Oncorhynchus mykiss). Fish Shellfish Immunol 35:1916-1923. https://doi.org/10.1016/j.fsi.2013.09.030

39. Pena-Torres EF, Davila-Ramirez JL, Pena-Ramos EA, Valenzuela-Melendres M, Pinelli-Saavedra A, Avendano-Reyes L, Gonzalez-Rios H (2021) Effects of dietary ferulic acid on growth performance, carcass traits and meat quality of heifers. J Sci Food Agric 101:548-554. https://doi.org/10.1002/jsfa.10666

40. Punitha SMJ, Babu MM, Sivaram V, Shankar VS, Dhas SA, Mahesh TC, Immanuel G, Citarasu T (2008) Immunostimulating influence of herbal biomedicines on nonspecific immunity in Grouper Epinephelus tauvina juvenile against Vibrio harveyi infection. Aquacult Int 16:511-523. https://doi.org/10.1007/s10499-007-9162-6

41. Reverter M, Bontemps N, Lecchini D, Banaigs B, Sasal P (2014) Use of plant extracts in fish aquaculture as an alternative to chemotherapy: Current status and future perspectives. Aquaculture 433:50-61. https://doi.org/10.1016/j.aquaculture.2014.05.048

42. Sadar SS, Vyawahare NS, Bodhankar SL (2016) Ferulic acid ameliorates TNBS-induced ulcerative colitis through modulation of cytokines, oxidative stress, iNOs, COX-2, and apoptosis in laboratory rats. Excil J 15:482-499. https://doi.org/10.17179/excli2016-393

43. Sarker U, Oba S (2020) Phenolic profiles and antioxidant activities in selected drought-tolerant leafy vegetable amaranth. Sci Rep 10:18287. https://doi.org/10.1038/s41598-020-71727-y

44. Silva ED, Batista R (2017) Ferulic acid and naturally occurring compounds bearing a feruloyl moiety: A review on their structures, occurrence, and potential health benefits. Compr Rev Food Sci Food Saf 16:580-616. https://doi.org/10.1111/1541-4337.12266

45. Soobrattee MA, Neergheen VS, Luximon-Ramma A, Aruoma OI, Bahorun T (2005) Phenolics as potential antioxidant therapeutic agents: mechanism and actions. Mutat Res 579:200-213. https://doi.org/10.1016/j.mrfmmm.2005.03.023

46. Valadez-García KM, Avendaño-Reyes L, Díaz-Molina R, Mellado M, Meza-Herrera CA, Correa-Calderon A, Macias-Cruz U (2021) Free ferulic acid supplementation of heat-stressed hair ewe lambs: Oxidative status, feedlot performance, carcass traits and meat quality. Meat Sci 173:108395. https://doi.org/10.1016/j.meatsci.2020.108395

47. Wang JL, Meng XL, Lu RH, Wu C, Luo YT, Yan X, Li XJ, Kong XH, Nie GX (2015) Effects of Rehmannia glutinosa on growth performance, immunological parameters and disease resistance to Aeromonas 
hydrophila in common carp (Cyprinus carpio L.). Aquaculture 435:293-300.

https://doi.org/10.1016/j.aquaculture.2014.10.004

48. Wang WW, Pan Y, Wang L, Zhou H, Song G, Wang YW, Liu JX, Li AK (2019) Optimal dietary ferulic acid for suppressing the obesity-related disorders in leptin-deficient obese C57BL/6J -ob/ob mice. J Agric Food Chem 67:4250-4258. https://doi.org/10.1021/acs.jafc.8b06760

49. Wang YX, Chen XL, Huang ZQ, Chen DW, Yu B, Yu J, Chen H, He J, Luo YH, Zheng P (2020) Dietary ferulic acid supplementation improves antioxidant capacity and lipid metabolism in weaned piglets. Nutrients 12:3811. https://doi.org/10.3390/nu12123811

50. Wen Y, Ushi H (2017) Ferulic acid promotes hypertrophic growth of fast skeletal muscle in zebrafish model. Nutrients 9:1066. https://doi.org/10.3390/nu9101066

51. Xu H, Zhang DL, Lv CH, Luo HY, Wang ZY (2015) Molecular cloning and expression analysis of scd1 gene from large yellow croaker Larimichthys crocea under cold stress. Gene 568(1). https://doi.org/100-108

.. 10.1016/j.gene.2015.05.027

52. Yan J, Liao K, Wang TJ, Mai KS, Xu W, Ai QH (2015) Dietary lipid levels influence lipid deposition in the liver of large yellow croaker (Larimichthys crocea) by regulating lipoprotein receptors, fatty acid uptake and triacylglycerol synthesis and catabolism at the transcriptional level. PLoS One 10:6-e0129937. https://doi.org/10.1371/journal.pone.0129937

53. Yao CW, Huang WX, Liu YT, Yin ZY, Xu N, He YL, Wu XF, Mai KS, Ai QH (2020) Effects of dietary silymarin (SM) supplementation on growth performance, digestive enzyme activities, antioxidant capacity and lipid metabolism gene expression in large yellow croaker (Larimichthys crocea) larvae. Aquacult Nutr 26:2225-2234. https://doi.org/10.1111/anu.13159

54. Yu LJ, Wen H, Jiang M, Wu F, Tian J, Lu X, Xiao JR, Liu W (2020) Effects of ferulic acid on growth performance, immunity and antioxidant status in genetically improved farmed tilapia (Oreochromis niloticus) fed oxidized fish oil. Aquacult Nutr 26:1431-1442. https://doi.org/10.1111/anu.13087

55. Yu LJ, Wen H, Jiang M, Wu F, Tian J, Lu X, Xiao JR, Liu W (2020) Effects of ferulic acid on intestinal enzyme activities, morphology, microbiome composition of genetically improved farmed tilapia (Oreochromis niloticus) fed oxidized fish oil. Aquaculture 528:735543. https://doi.org/10.1016/j.aquaculture.2020.735543

56. Yu LJ, Wu F, Jiang M, Yang CG, Liu W, Tian J, Lu X, Wen H (2016) Ferulic acid: A natural compound as an efficient feed additive for GIFT (Oreochromis niloticus). Aquacult Nutr 24:27-35. https://doi.org/10.1111/anu.12529

57. Yuan XY, Wang CC, Huang YY, Dai YJ, Desouky HE (2020) A comparative study on intestinal morphology and function of normal and injured intestines of Jian carp (Cyprinus carpio var. Jian). Aquaculture 528:735496. https://doi.org/10.1016/j.aquaculture.2020.735496

58. Zemheri-Navruz F, Acar U, YIlmaz S (2019) Dietary supplementation of olive leaf extract increases haematological, serum biochemical parameters and immune related genes expression level in common carp (Cyprinus carpio) juveniles. Fish Shellfish Immunol 89:672-676.

https://doi.org/10.1016/j.fsi.2019.04.037

Page 19/21 
59. Zhao JZ, Ai QH, Mai KS, Zuo RT, Luo YW (2013) Effects of dietary phospholipids on survival, growth, digestive enzymes and stress resistance of large yellow croaker (Larmichthys crocea) larvae. Aquaculture 410:122-128. https://doi.org/10.1016/j.aquaculture.2013.05.018

60. Zheng XX, Cheng Y, Chen YW, Yue YS, Li YC, Xia SZ, Li Y, Deng HH, Zhang JL, Cao YJ (2019) Ferulic Acid Improves Depressive-Like Behavior in Prenatally-Stressed Offspring Rats via Anti-Inflammatory Activity and HPA Axis. Int J Mol Sci 20:493. https://doi.org/10.3390/ijms20030493

61. Zhou ZK, Shi TX, Hou J, Li M (2020) Ferulic acid alleviates atopic dermatitis-like symptoms in mice via its potent anti-inflammatory effect. Immunopharmacol Immunotoxicol 42:156-164. https://doi.org/10.1080/08923973.2020.1733012

62. Zhu LJ, Zhang ZS, Xia NN, Zhang WF, Wei YL, Huang JS, Ren ZJ, Meng FL, Yang L (2020) Anti-arthritic activity of ferulic acid in complete Freund's adjuvant (CFA)-induced arthritis in rats: JAK2 inhibition. Inflammopharmacology 28:463-473. https://doi.org/10.1007/s10787-019-00642-0

63. Zuo RT, Ai QH, Mai KS, Xu W (2013) Effects of conjugated linoleic acid on growth, non-specific immunity, antioxidant capacity, lipid deposition and related gene expression in juvenile large yellow croaker (Larmichthys crocea) fed soyabean oilbased diets. Br J Nutr 110:1220-1232. https://doi.org/10.1017/S0007114513000378

\section{Figures}

\section{Figure 1}

Effects of supplementation of ferulic acid (FA) on antioxidant capability in visceral mass of large yellow croaker larvae. A: T-SOD, total superoxide dismutase; B: CAT, catalase; C: T-AOC, total antioxidant capacity; D: MDA, malondialdehyde. Values are means $(n=3)$, with their standard errors represented by vertical bars. Bars bearing the same letters were not significantly different ( $P>0.05$, Tukey's test).

\section{Figure 2}

Effects of supplementation of ferulic acid (FA) on immune capability of large yellow croaker larvae. A: LZ, lysozyme; B: T-NOS, total nitric oxide synthase; C: iNOS, inducible nitric oxide synthase; D: NO, Nitric Oxide. Values are means $(n=3)$, with their standard errors represented by vertical bars. Bars bearing the same letters were not significantly different ( $P>0.05$, Tukey's test).

\section{Figure 3}


Effects of supplementation of ferulic acid (FA) on triglyceride content and relative mRNA expression of genes involved in lipid metabolism in visceral mass of large yellow croaker larvae. A: the triglyceride content; B: the relative mRNA expression of genes involved in lipogenesis; $C$ : the relative mRNA expression of genes involved in lipid consumption; $D$ : the relative mRNA expression of genes involved in lipid transportation. Values are means $(n=3)$, with their standard errors represented by vertical bars. Bars bearing the same letters were not significantly different ( $P>0.05$, Tukey's test). 